\title{
Challenges in Learning Legal English from Students' Perspective at Hanoi Law University
}

\author{
Huong Thanh Nhac \\ Hanoi Law University, Vietnam \\ nhacthanhhuong@gmail.com
}

DOI: http://doi.org/ 10.36892/ijlls.v3i3.675

\begin{tabular}{|c|c|}
\hline $\begin{array}{l}\text { Received: } \\
\text { 12/08/2021 }\end{array}$ & $\begin{array}{l}\text { Abstract } \\
\text { Legal English, also known as Language of the Law (Mellinkoff, 2004), is an }\end{array}$ \\
\hline $\begin{array}{l}\text { Accepted: } \\
25 / 09 / 2021\end{array}$ & $\begin{array}{l}\text { dispensible factor contributing to the development of legal field. At Hanoi Law } \\
\text { University, Legal English is a compulsory subject in the syllabus of legal } \\
\text { English majors and International Trade Law majors. The question that what } \\
\text { obstacles students face when dealing with legal English, however, has not }\end{array}$ \\
\hline $\begin{array}{l}\text { Keywords: } \\
\text { Challenges; Legal } \\
\text { English; Students' } \\
\text { perspective; Hanoi } \\
\text { Law University }\end{array}$ & $\begin{array}{l}\text { been fully answered at this institution. This present research,which makes use } \\
\text { of survey questionnaires as the main method, aims to study the challenges of } \\
\text { learning legal English from the students' perspective. The results indicate } \\
\text { notable difficulties arising from the distinctive characteristics of legal English, } \\
\text { differences in legal systems between jurisdictions and insufficient background } \\
\text { knowledge of the laws. It is expected that these findings propose a number of } \\
\text { practical recommendations in order to improve the effectiveness of the } \\
\text { process of learning and teaching legal English. }\end{array}$ \\
\hline
\end{tabular}

\section{INTRODUCTION}

Legal English is a form of English used in the field of law of England, America and other countries whose official language is English (Veretina-Chiriac, 2012). Specifically, legal English is a specialized language for legal purposes, which is basically used by legal professionals such as lawyers; judges; prosecutors, etc., in their work (Goga-Vigaru, 2015). It is undeniable that in the era of globalization, exposure to different legal systems requires legal practitioners to communicate successfully in English using the appropriate legal language and terminology. Moreover, currently, most of international conventions, international treaties, constitutions, regulations are written in English (Garner, 1989). It is necessary that legal experts both master knowledge of law and have a good command of legal English. Including legal English into the curriculum of law schools throughout the world, therefore, is becoming of great importance (Supardi, 2013).

Legal English is considered difficult to understand even for native speakers because of its unusual linguistic features. Legalese, the language used by lawyers and in legal documents, makes it difficult for ordinary people to understand. It is "incomprehensible verbiage found in legal documents as well as an arcane jargon used among attorneys" (Schane, 2006, p.2). Therefore, it is determined that mastering legal English by graduates whose native language is not English allows them to understand legal traditions, rules and values not only of native speakers but of other nationalities as well. 
At Hanoi Law University, legal English is the core subject of English major and International Trade Law major training program. Besides enhancing the quality of legal education, the questions of how to teach and learn legal English effectively has gained a great concern among lecturers and learners for the past few years. During the process of teaching legal English, the writer has realized that learners at Hanoi Law University clearly have been facing plenty of challenges. This affects the quality of both teaching and learning legal English at this institution. In the literature, a limited number of studies have been carried out to find out the difficulties in learning and teaching legal English in tertiary contexts. Similarly, there has been little research work to identify challenges learners meet in the context of Hanoi Law University. This fact suggests a need for carrying out the research to clarify obstacles in learning legal English from students' perspective at this higher education institution.

\section{LITERATURE REVIEW}

\subsection{Legal English and its characteristics}

Legal English is the style of English used by lawyers and other legal professionals in the course of their work (Supardi, 2013). Legal English shares many similarities with other types of English for specific purposes (ESP) in that each type of ESP has its own set of technical terminology and special syntax (Supardi, 2013). However, legal English differs from general English because of its unusual features related to terminology, linguistic features and punctuation. Generally, legal English is distinctive in terms of lexical and syntactic features (Veretina-Chiriac, 2012).

\section{Lexical features}

The use of archaisms: Archaic terms refer to the use of old expressions by lawyers called legalese such as pursuant to (under; in accordance with); prior to (before); subsequent to (after), etc., which makes it hard for laypersons to understand (Veretina-Chiriac, 2012). Although legal practitioners have had a tendency to simplify the legal English by replacing them with more understandable forms, that is "Plain English" movement (Mellinkoff, 2004), a variety of archaic words, e.g. hereinafter; aforesaid; therein; thereto; thereof can still be found in English legal documents under common law legal system.

The use of technical terms: In the field of law, technical terms refer to pure legal terms. Some of them are familiar to laypersons (patent, share, royalty), while others, are generally only known to lawyers (bailment, abatement). In the later case the problem of miscomprehension of legalisms emerged" (Hiltunen, 1999, p.150). Also, there are common words with uncommon meanings in specific legal contexts, e.g., "attachment, action, consideration, execute, party" (Rylance, 1994, p.36). Those are examples of a specialized language that enables persons working in the legal field to communicate quickly and efficiently (Veretina-Chiriac, 2012).

The use of foreign words/ borrowed words: A considerable number of Latin and French words and phrases are found in legal English (Veretina-Chiriac, 2012). Words of Latin origin include: negligence, inferior, versus, pro se, stare decisis, obiter dictum, etc., Moreover, the influence of French is shown not only in the words of French origin (appeal, claim, complaint, court, default), but also in the position of adjectives behind the modified nouns in phrases such as: attorney general, fee simple absolute, state auditor general, etc. (Veretina-Chiriac, 2012).

The use of synonymy: The use of synonyms is also a prominent feature in legal English (Veretina-Chiriac, 2012). According to Haigh (2004), a large number of synonyms referring to the same legal concept, e.g., assign - transfer; breach - violation; clause provision - article; etc., makes legal drafting and writing more challenging and complicated. 
Also, most common types of synonym pairs, called binomials, are the use of doublets and triplets with the conjunction "and", e,g: act and deed, legal and valid, goods and chattels, null and void, etc., one of which is redundant and does little to the meaning itself (Garner, 1989).

\section{Syntactic features}

Sentence length: It can be seen that one main linguistic feature of legal document is using complex and compound sentences instead of simple ones. Sentences in legal documents include a great deal of information, repetitiveness, noun phrases with plenty of modification as well as coordinate and subordinate clauses (Veretina-Chiriac, 2012).

Nominalization: Nominalization is often claimed to be used in formal writings, and legal writing is not an exception. Nominalization refers to the nouns derived from verbs, which are often used instead of verbs, such as to give consideration instead of to consider, to be in opposition rather than to oppose, etc,. It is noted that nominalization makes the text long and non-dynamic, however, it is hard to eradicate nominalization in legal English documents (Bhatia, 1993).

Impersonal style: Impersonal style refers to not only the use of third person (everybody, nobody, every person) but also passive voice (Veretina-Chiriac, 2012). The use of impersonal style creates the impression that law is impartial. However, such generalizations are vague and make it obscure to people who do not specialize in law (Veretina-Chiriac, 2012).

\subsection{Previous studies on challenges in teaching and learning Legal English}

In the field of language education, teaching and learning legal English has been regarded as uniquely different and difficult from other areas of ESP (Gibbons, 2003). In the literature, there has been an amount of research on difficulties of teaching and learning legal English carried out in different contexts but to some extent, shared the similar findings.

As stated, legal English, like other forms of ESP, has its own specific linguistic features, which result in the difficulty in understanding and interpreting legal terms, and legal procedures. From the linguistic point of view the transfer of the meaning and interference with the other languages and mother tongue present major difficulties for both teachers and learners as it is quite difficult to cope with Law and language simultaneously. Learners have to focus not only on general English, they also have to focus on specialized vocabulary, e.g., legal English (Saliu, 2013). White (1982) indicated that one of the most problematic features of legal discourse was "invisible" (p.423). He claims that "the most serious obstacles to comprehensibility are not the vocabulary and sentence structure employed in law, but the unstated conventions by which language operates." (p.423)

Т.П.Попова (2008) carried out a research in the context of her institution in Russia, a civil law country. Textbooks used in this context were published by UK publishing houses. It is common knowledge that the UK follows the Common - law tradition, which clearly differs from Russian law based on civil law tradition. The findings showed that the difficulties in learning legal English primarily arose from the legal terms and the differences in the legal systems between Russia and the UK. This proves the fact that legal languages are shaped by the legal system in which they are used, so there is no universal legal language. She also specified that teaching and learning legal English met many challenges including the differences between Common law and legal system of learners; the difference between teachers and learners' cultures; even the restrictions on the source of legal English textbooks and reference books.

Butler (2015) indicated that legal writing was the most complicated skill among four skills for both teachers and learners. It is partly explained because of the fact that most teachers of legal English are language teachers, not legal experts. Therefore, they lack 
experience in writing and drafting legal correspondence and legal documents.

Toska (2019) revealed that teaching legal English as a second language raises two language related challenges for both teachers and learners. The first challenge is concerned with the peculiarities of legal English terminology and sentence structure. The second challenge focuses on the cultural differences between legal systems. Law is deemed to be an extremely precise and concise discipline, therefore, legal principles must be interpreted in the context of specific legal system. Because different legal systems had different legal rules and legal concepts, the semantic domains of legal terms did not correspond with one another (Mattila, 2006). The purpose of teaching legal English is to prepare students to practice law and familiarize them with terminology. This can be achieved through the use of legal texts which help students develop a real understanding of legal terms and subjects.

All studies partly show the challenges in learning and teaching legal English in different aspects. In the light of these previous studies, this current research was carried out to investigate the difficulties in learning legal English from the learners' perspective in the context of Hanoi Law University.

\section{METHODS}

\subsection{Participants}

120 legal English major juniors at Hanoi Law University took part in the survey. All participants have finished two basic legal English courses. Concerning general English capacity, it was determined that they were between intermediate and upper-intermediate level of proficiency based on the English test they took at the beginning of the course. In terms of background knowledge of the law, it should be noted that law is not the major of legal English students. Consequently, learners shared the similar characteristics in the sense that they did not have enough knowledge of the law subject at the time of studying legal English.

\subsection{Settings}

At Hanoi Law University, legal English majors are required to study four legal English courses. The textbooks used are Professional English in Use - Law; Introduction to International Legal English; International Legal English - which are all published by UK publishing houses. It is widely known that the UK follows the Common - law tradition, which is different from Vietnamese legal tradition based on Civil law. Moreover, the content of legal English curricula includes a wide range of topics ranging from civil law, criminal law, tort law, contract law, commercial law; company law, international law, and even real property law. As mentioned above, due to the fact that law is not the participants' majors, they lack necessary background knowledge of the majority of law areas.

\subsection{Data collection instrument}

Survey questionnaire is the main method to collect data about the learners' perceptions of the difficulties in learning legal English. The questionnaires consisted of 2 questions asking for learners' overall attitudes and level of satisfaction of legal English courses. The next part is made up of 18 items on a 5-point Likert Scale. Among the 18 items, 9 items (1-9) belong to the features of legal English, 3 items (10-12) arising from the differences in Vietnamese and English legal systems, and the rest 6 items relating to background knowledge of legal fields and practice. The participants were expected to indicate (1) strongly disagree, (2) disagree, (3) undecided, (4) agree, (5) strongly agree. The last open-ended question seeks learners' choice relating to the most difficult legal English skills among four skills. The questionnaire was shown to be reliable through the overall 
Cronbach Alpha Coefficient of the questionnaire $(r=.867)^{1}$, which proved to be a good indicator of internal consistency. The validity of the questionnaire was confirmed by three experienced instructors of legal English.

\subsection{Procedures of data collection and data analysis}

At the end of the second legal English course in the academic year of 2020-2021, the survey questionnaires were administered to 120 legal English major juniors' email address. The respondents were requested to return the questionnaire after one week since the date of email-shot to ensure that all issues in the survey were considered carefully before replying. The data was then collected and coded for the purpose of the data treatment. SPSS program was used to analyze the data quantitatively. Specifically, frequency count, percentage and descriptive mean were employed to address the difficulties in learning legal English with Likert scales, particularly the mean value of each item can be interpreted as follows (1.01.79) strongly disagree, (1.8-2.59) disagree, (2.6-3.39) neutral, (3.4-4.19) agree, and (4.2-5.0) strongly disagree.

\section{RESULTS AND DISCUSSION}

Participants' attitudes towards the importance of legal English

Figure 1: Learners' attitude towards the importance of legal English

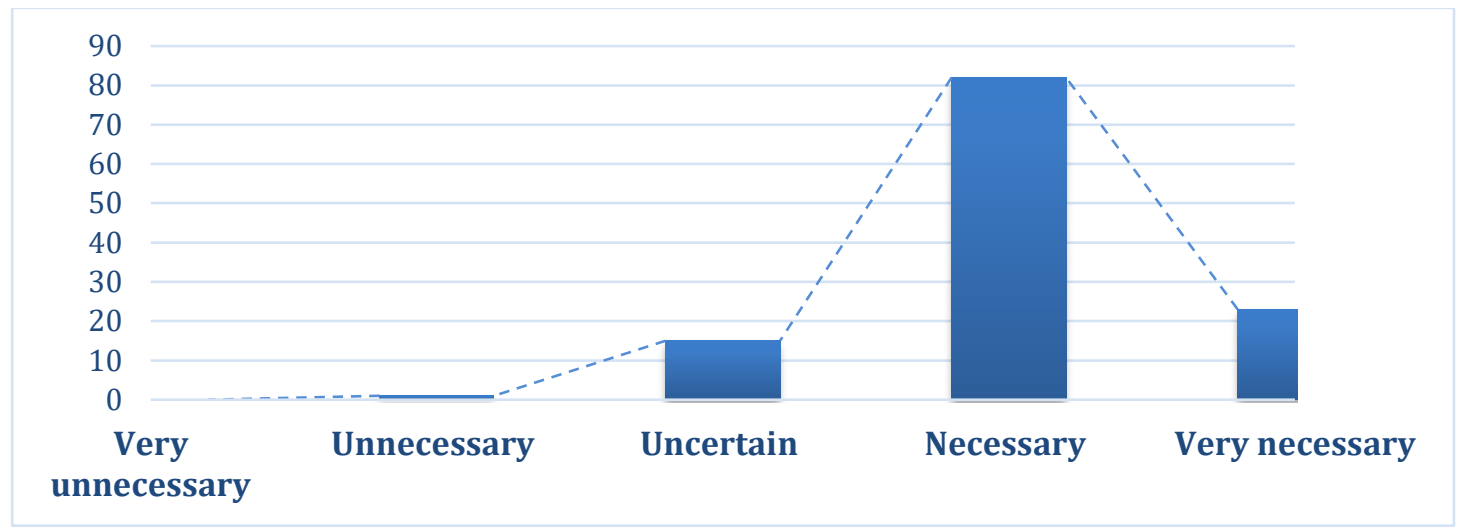

The chart 1 illustrates the learners' perceptions on the importance of legal English. It is obvious that most students surveyed were self-conscious that legal English was of great importance. The number of participants choosing it necessary and very necessary accounted for 82 (among 120 students). Realizing the necessity of legal English is considered to be one of the main motivations for students to acquire legal English.

Figure 2: Learners' satisfaction towards the content of the legal English courses

\footnotetext{
${ }^{1}$ Cronbach, L. J. (1951). Coefficient alpha and the internal structure of tests. Psychometrika, 16(3), $297-334$. doi:10.1007/bf02310555.
} 


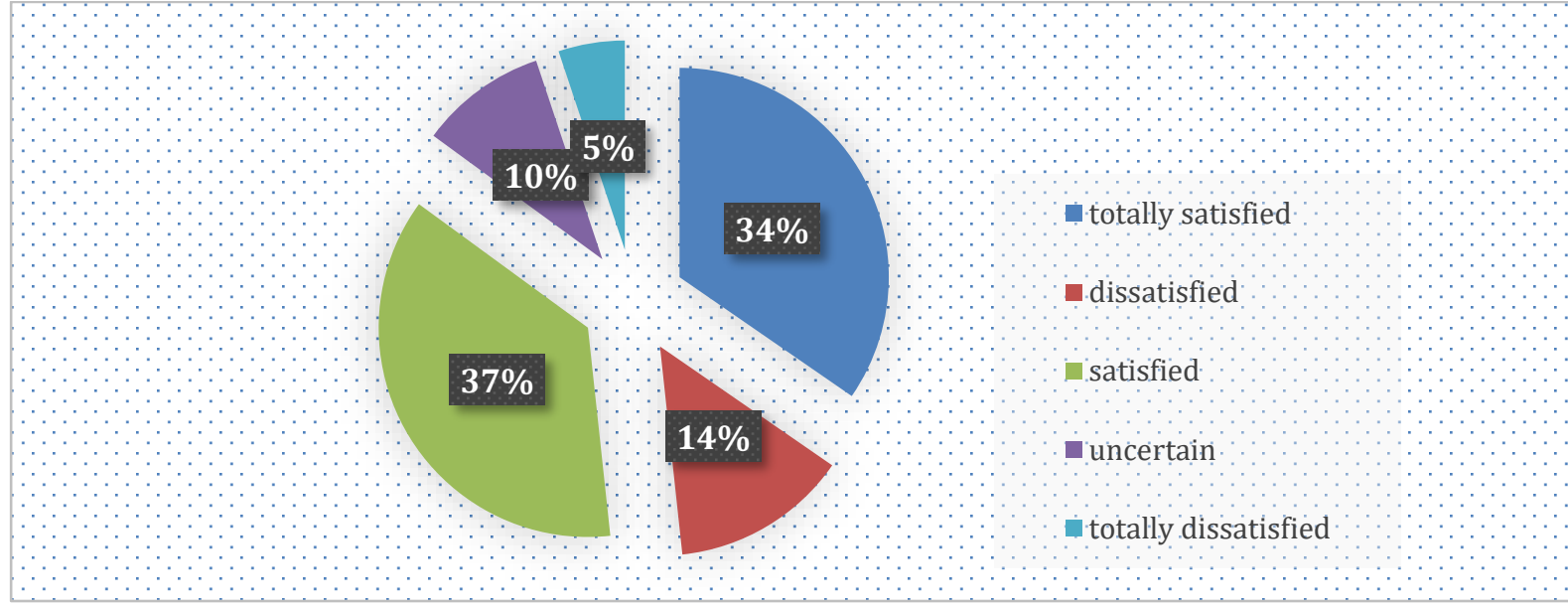

The chart 2 shows that the majority of learners felt satisfied and totally satisfied with the content of the legal English courses, which accounted for 37\% and 34\% respectively. $19 \%$ of learners who found the legal English courses dissatisfying gave the reason that the course did not provide enough opportunities for them to acquire practical skills.

Challenges in learning legal English from students' perspective

Table 1 shows the factors contributing to difficulties in learning legal English from learners' perspectives.

Table 1: Learners' perceptions of the difficulties in learning legal English

\begin{tabular}{|l|l|l|}
\hline \multicolumn{1}{|c|}{ Items } & Mean & SD \\
\hline 1. Use of common words with uncommon meaning & 4.12 & .710 \\
\hline 2. Double and triple synonyms & 3.94 & .612 \\
\hline 3. Archaic words & 4.27 & .646 \\
\hline 4. Latin terms & 4.33 & .516 \\
\hline 5. French borrowed words & 3.66 & .740 \\
\hline 6. Use of passive structure & 3.90 & .594 \\
\hline 7. Nominalisation & 3.89 & .651 \\
\hline 8. Long, complex sentences & 4.17 & .617 \\
\hline 9. Impersonal style & 3.06 & .730 \\
\hline 10. Highly specialized concept & 4.50 & .548 \\
\hline 11. Non-equivalent legal terms & 4.44 & .605 \\
\hline 12. Unfamiliar legal areas and topics & 4.05 & .546 \\
\hline 13. Insufficient background knowledge of Vietnamese law & 4.17 & .617 \\
\hline 14. Insufficient background knowledge of Common-law traditions & 4.50 & .548 \\
\hline 15.Lack of skills of researching legal documents & 4.17 & .753 \\
\hline
\end{tabular}




\begin{tabular}{|l|l|l|}
\hline 16. Lack of skills of analyzing legal documents & 4.45 & .713 \\
\hline 17. Lack of practical skill of drafting legal correspondence & 4.27 & .646 \\
\hline 18. Lack of practical skill of doing advocacy in adversarial context & 4.83 & .408 \\
\hline
\end{tabular}

As seen from the table 1, the results show that 8 out of 9 distinctive features of legal English listed were deemed to be challenging, with the high mean score of agreement ranging from 3.66 to 4.33 . The participants strongly agreed that the use of Latin terms in legal texts made them find it difficult to study with the mean value of 4.33. Archaic words and long, complex sentence stood on the next ranks of challenging level with the mean value of 4.27 and 4.17 respectively. Other linguistic features of legal English such as the use of common words with uncommon meaning (4.12); double and triple synonyms (3.94), use of passive structure (3.90) and nominalization (3.89) received the high rate of agreement among participants to be problematic factors. The item "French borrowed words" was not considered to be a really big problem to learners while impersonal style is the only characteristic perceived to be neither difficult nor easy. In general, there is no doubt that linguistic features of legal English cause great problem to learners as most of the students agreed with the items surveyed in questionnaires.

Concerning the differences between two legal systems, Vietnamese and English ones, all participants strongly agreed that highly specialized concepts, non-equivalent legal terms; unfamiliar legal areas and topics were the difficulty in the process of acquiring legal English with the high mean value of agreement of $4.50 ; 4.44$ and 4.05 respectively. It gave no surprise to the researcher because of the fact that the semantic domains of legal terms did not correspond with one another (Mattila, 2006). As a result, the translation of legal concepts was complex and could lead to severe misunderstandings (Goode, 2014). One example is the concept of "consideration". In general English, "consideration" simply means "care". However, in the contract field under English law, "consideration" - a key element in the formation of contract, refers to a promise given in exchange for another promise. However, there is no equivalent term in Vietnamese. Such intercultural differences between various legal systems are of central importance to legal language and cause frequent misunderstandings in international legal communication.

Insufficient background knowledge of Vietnamese Law and English law as well as practical skills of drafting, researching, analyzing legal documents are contributing factors to difficulties in studying legal English. Not surprisingly, all of the items received high rate of agreement among learners with the highest mean value of the lack of advocacy practical skills and insufficient knowledge of Common-law traditions, accounting for 4.83 and 4.50 respectively. It should be noted that the participants involved in the study were English majors, therefore, the lack of background knowledge of Vietnamese law seemed to be one of the biggest challenges for them. Other aspects relating to lack of practical skill of drafting legal correspondence, lack of skills of researching legal documents and insufficient background knowledge of Vietnamese law also are big challenges in learning legal English.

Figure 3: Learners' perceptions towards the difficulty of four legal English skills 


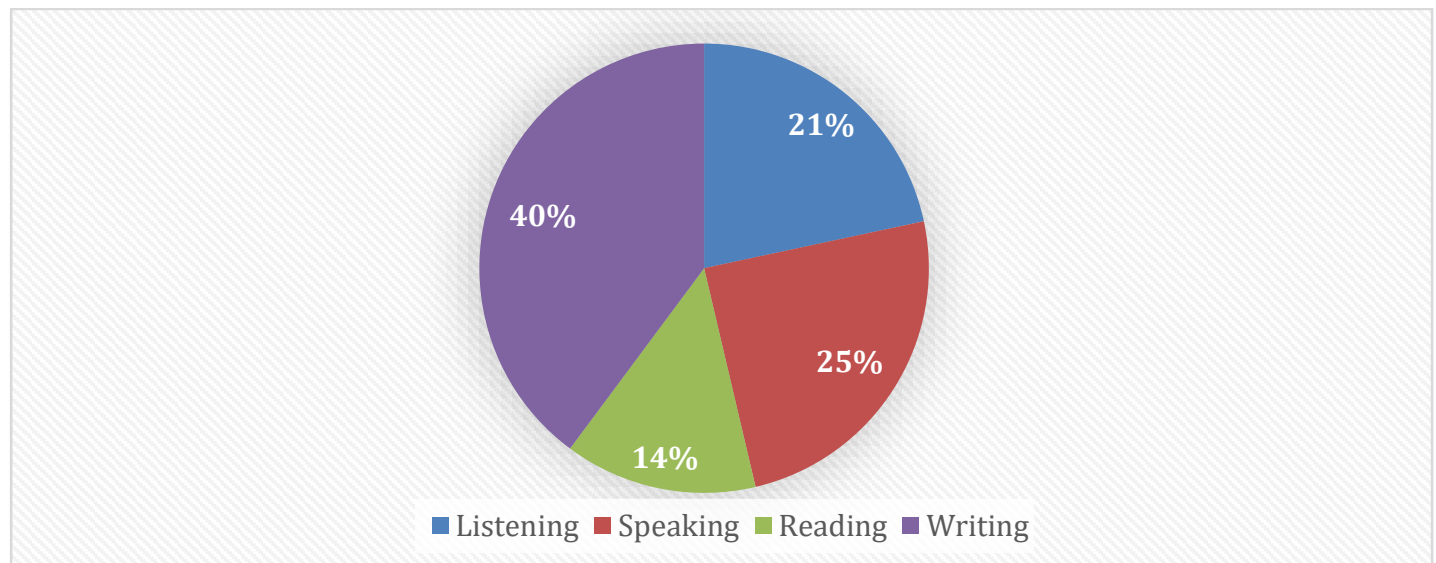

The pie chart indicates that a high percentage of legal English major juniors $(40 \%)$ shared the same opinion when considering legal writing as the most challenging skill. Legal speaking and legal listening stood on the next ranks with the rate of $25 \%$ and $21 \%$ respectively. It seemed to be easy to understand because at Hanoi Law University, the legal English curricula mainly focused on legal reading and listening to provide inputs for learners before leaving them opportunities for productive skills such as legal writing and speaking.

In general, the findings reflect the real challenges of learning legal English among English majors at Hanoi Law University including the main ones arising from linguistic features of legal English, the differences in legal systems as well as lack of background knowledge in law and practical skills in legal practicing.

\section{IMPLICATIONS}

The study was designed to examine the challenges in learning legal English of English majors in the context of Hanoi Law University. The study indicates that legal English has its own features different from ordinary English, which makes it difficult for learners. Also, the cultural differences between legal systems of countries lead to the non-equivalence of the high specialized concepts. These findings suggest some pedagogical implications for language teachers, which are presented subsequently.

Firstly, it is advisable that students are required to be equipped with content of law knowledge before being taught legal English. Although legal English majors do not need to master legal concepts, it should be noted that when structuring a legal English course, teachers have to provide information regarding their own legal systems. Teachers are advised to incorporate the basic legal principles in English to equip learners with background knowledge of laws. A variety of legal topics including criminal law, tort law, contract law, company law, commercial law, international law, etc., should be introduced to learners. In other words, law subject classes should precede legal English classes to ensure that learners can acquire legal English learning effectively.

Secondly, a review of language and grammar will be of great value for legal English teaching context. In a different legal topic, learners should be provided with a wide range of language exercises covering the distinctive features of legal English, for example, the use of Latin terms, borrowed words, or common words with uncommon meaning. Those exercises also should include legal skills practice and role-play such as advocacy, interviewing, negotiation and drafting, enabling them to develop their proficiency in legal English. Such kinds of activities can be provided through the application of high technology in blended lessons, e.g., mobile devices in order to develop students' motivation (Kappalumakkel, 2020). In other words, by this way language teachers can offer the learners stimulating and enjoyable instruction designed to progressively enhance relevant and meaningful students' communication skills in oral and written legal English as well as legal reading and listening skills. Moreover, using authentic materials of legal cases for learners to present and practice 
legal language is highly recommended. It is undeniable that nothing is more precious than offering them simulated real-life cases to practice.

Lastly, due to globalization, legal practitioners from different legal cultures and language backgrounds have a tendency to use English as a medium of communication. However, the basic problem of the mismatch between national legal systems of countries, on the one hand, and common and civil law systems on the other hand, has meant that the study of comparative law proves to be of great importance. For this point, legal English teachers can adopt CLIL approach (Content and Language Integrated Learning) to teaching legal English, which combines legal language teaching with teaching the features of the other legal systems for the purpose of contextualized meaning. Those suggestions require a great effort of legal English language teachers and support from law teachers.

\section{CONCLUSION}

This study demonstrates the challenges of learning legal English faced by English majors at Hanoi Law University. Those difficulties arise from the distinctive features of legal English, the differences between legal systems and insufficient legal background knowledge. From the findings, a number of pedagogical implications have been drawn up with a view to enhancing the effectiveness of the process of legal English acquisitions. However, there are several limitations to the current study. Firstly, the study was conducted to find out the difficulties in learning process from the learners' perspective, teachers' perceptions were not taken into consideration in this study. Secondly, the number of participants, which restricted to English majors, was rather limited. Law students were not involved in this study, the results, to some extent, cannot reflect the behaviour of a larger population in different settings or contexts. Therefore, in order to have a detailed insight, further research should be carried out to fill in the research gaps.

\section{REFERENCES}

Butler, D. B. (2013). Strategies for Clarity in L2 Legal Writing. Journal of the International Association Promoting Plain Legal Language. Clarity 70. https://www.clarityinternational.org/wp-content/uploads/2020/07/Clarity-no-70-web-bookmarked.pdf

Garner B. A. A Dictionary of Modern Legal Usage - Oxford: Oxford University Press, 1989.

Goode, R. (2014). Communication on European Contract Law. Retrieved from www.law.ox.ac.uk/profile/gooder.

Haigh, R. (2009). Legal English. (2 ${ }^{\text {nd }}$ ed.). New York: Routledge-Cavendish.

Heikki E. S. Mattila. (2006). Comparative Legal Linguistics. Hampshire: Ashgate.s

Hiltunen R. Chapterson.(1999). Legal English - Helsinki: Suomalainen Tiedeakatemia,

Kappalumakkel, T. B. (2020). Application of Mobile Phone as a Motivational Tool in the ESP Classrooms of Dhofar University. International Journal of Language and Literary Studies, 2(1), 81-89. https://doi.org/10.36892/ijlls.v2i1.116

Matilla, Heikki E. S. (2006). Comparative Legal Linguistics. Aldershot: Ashgate Publishing Limited.

Mellinkoff, D. (2004). The Language of the Law. Resource Publications. 
Goga-Vigaru, RP (2015). Challenges in teaching legal English and efficient methods of evaluating Romanian students at the Faculty of Law and Public Administration. Conference Proceedings, SlovakEdu. https://www.slovakedu.com/publications/clear2015-conference-proceedings/a05/

Saliu, B. (2013). Challenges for learners/ teachers in the ESP course for legal studies. SEEU Review, (9), 1. http://doi.org/10.2478/seeur-2013-0001.

Schane, S (2006). Language and the law. UCSD Linguistics.

Supardi, M.Pd. (2013). Developing Materials for Teaching Legal English Vocabularies with the Internet Use. International Journal of English and Education, 2(2).

Toska, I. (2019). Teaching Legal English in Multilevel classes. Section 2. Higher Education. https://cyberleninka.ru/article/n/teaching-legal-english-in-multilevel-classes/viewer

Т.П.Попова. (2008). The challenges in teaching and learning Legal Writing. Higher School of Economics, Moscow. https://www.hse.ru/data/2014/02/14/1328274884/Legal\%20writing_Tatiana_Popova .pdf

Veretina-Chiriac, Ina. (2012). Characteristics and features of legal English vocabulary. Revistă Ştiinţifică a Universităţii de Stat din Moldova, nr.4 (54). http://studiamsu.eu/wp-content/uploads/20.-p.103-107.pdf

White, J. B. (1982). The Invisible Discourse of the Law. Reflections on Legal Literacy and General Education. Michigan Quarterly Review, 21.

\section{Appendix}

This questionnaire aims at investigating students' challenges in learning legal English at Hanoi Law University. This questionnaire will be used for the purpose of data analysis. I look forward to receiving your cooperation and ensure that your information is only for educational purposes.

1. In your opinion, what is the necessity level of legal English in the training program you are studying?
Very unnecessary
$\square$ Unnecessary
$\square$ Uncertain
$\square$ Necessary
Very necessary

2. Are you satisfied with the curriculum and content of English for legal purposes?
Totally dissatisfied
$\square$ Dissatisfied
$\square \quad$ Uncertain
$\square \quad$ Satisfied
$\square$ Totally satisfied

3. What are the challenges in learning legal English? Please tick $(\checkmark)$ your choice. 
Challenges in Learning Legal English from Students' perspective at Hanoi Law University

( $\mathrm{SD}=$ strongly disagree; $\mathrm{D}=$ disagree $; \mathrm{N}=$ neutral $; \mathrm{A}=$ agree $; \mathrm{SA}=$ strongly agree $)$

\begin{tabular}{|l|l|l|l|l|l|}
\hline Items & SD & D & N & A & SA \\
\hline 1. Use of common words with uncommon meaning & & & & & \\
\hline 2. Double and triple synonyms & & & & & \\
\hline 3. Archaic words & & & & & \\
\hline 4. Latin terms & & & & & \\
\hline 5. French borrowed words & & & & & \\
\hline 6. Use of passive structure & & & & & \\
\hline 7. Nominalisation & & & & & \\
\hline 8. Long, complex sentences & & & & & \\
\hline 9. Impersonal style & & & & & \\
\hline 10. High specialized concept & & & & & \\
\hline 11. Non-equivalent legal terms & & & & & \\
\hline 12. Unfamiliar legal areas and topics & & & & \\
\hline $\begin{array}{l}\text { 13. Insufficient background knowledge of Vietnamese } \\
\text { law }\end{array}$ & & & & & \\
\hline $\begin{array}{l}\text { 14. Insufficient background knowledge of Common- } \\
\text { law traditions }\end{array}$ & & & & & \\
\hline 15.Lack of skills of researching legal documents & & & & \\
\hline 16. Lack of skills of analyzing legal documents & & & & \\
\hline 17. Lack of practical skill of drafting practical skill of doing advocacy context & & & & \\
\hline
\end{tabular}

4. Among four legal English skills (Listening, Speaking, Reading and Writing), which skill do you find the most challenging?

5. Can you suggest some solutions to overcome the challenges in learning legal English?

Thank you for your co-operations! 


\section{AUTHOR'S BIO}

Huong Thanh Nhac is currently an instructor of English at Foreign Languages Department at Hanoi Law University. She earned MA degree at University of Languages and International Studies, Viet Nam National University. Her research interests include EFL and ESP teaching methodology, learning autonomy, student motivation and encouragement. 